\title{
Solid Financial Reforms are Needed to Uplift the Distressed Real Estate Sector
}

\author{
Syed Hasan Jafar ${ }^{1}$ \\ ${ }^{1}$ Assistent Professor, Department of Finance, Woxsen University, Hyderabad, India
}

*Correspondence: Syed Hasan Jafar; Email: syedhasan.jafar@woxsen.edu.in

\begin{abstract}
After the pandemic COVID-19 breakout, there has been a significant decline in the property listings. Though the Centre has focused on the affordable housing space for reforms, there has been no visible reforms in view of the realty developers. Due to the recent moratorium imposed on the term loans, credit sources have been tightened for the realty developers coupled with other aspects. Given the difficulty in credit availing conditions in the sector, the article discusses the distressed funds as alternatives to uplift the sector. However, there are certain hurdles for the distressed funds in the form of capital structures to act quickly and operate efficiently. The article in this regard discusses certain changes in the regulatory framework that allows flexibility in the capital outlay in the residential real estate projects.
\end{abstract}

Keywords: Financial reforms, Real estate, ARC, AIF, Loan, Bank

\section{ARTICLE INFORMATION}

Author(s): Syed Hasan Jafar

Received: 01 Sep, 2020; Accepted: 31 Oct, 2020; Published: Article-In-Press; e-ISSN: $2347-4696$;

Paper Id: BMN-IJBMR-2020-8;

Citation: doi.org/10.37391/IJBMR.080401

crossef member

Webpage-link: www.ijbmr.forexjournal.co.in/archive/volume-8/ijbmr-080401.html

\section{COMMENTARY}

Recently, Magicbricks, a times group realty online portal, revealed that the real estate prices across 8 metro cities in India dipped by $5 \%$. The property listings on the portal were down by $42.5 \%$ for the April to June Quarter 2020. This explains the new headwinds being faced off by the realty sector due to the COVID-19 pandemic. The sector has to face the current situation even before the stressed effects of the GST and demonetisation are yet to be fully absorbed. In the recent past, as the deliveries of the promised projects were not in time and as there were volumes of cases of the consumers getting into the heavy debt traps due to the unfinished home projects, the government and the judiciary prioritized the concerns of the home buyers'. As a result, the reforms in the sector were invisible, apart from the affordable housing space, in view of the reality developers. On the other side, the housing finance companies are restraining themselves to give new loans to the developers due to the moratorium imposed by the RBI on all term loans. RBI taking over the reins of the National Housing Bank to regulate the funding norms of the sector is also tightening the Credit sources. This may create a sense of despair among the realty developers.

Recently in June 2020 RBI has issued draft guidelines for the housing finance companies and the draft is currently seeking stakeholders' comments. These guidelines by RBI intend that HFCs need to increase their exposure to retail individual borrowers. The exposure is to the tune of a minimum of $37.5 \%$ of the HFCs' total assets minus current assets (bank balance, cash, and money market instruments). This would gradually reduce the HFCs current exposure to reality developers. So far, in significant cases, HFCs played double funding by lending both to the developer and the retail buyers of the same project. By providing credit support to the developers for construction, they had an advantage of lending to the retail buyers as well of the same project. However, it is mulled and proposed that the HFCs need to lend only to one of either party but not to both.

As the IBC code is suspended for about six months, it is important that for the sector to restructure and rehabilitate alternative channels of funding. Such an alternative would be the distressed funds which would take the risk to buy the distressed company's debt at a discount. They would do this if the fund houses believe that there would be a significant turnaround in the industry and eventually the value of the debt goes up significantly over time. But for the distressed funds to operate quickly and efficiently, they seek a flexible capital structure to control both the equity and debt of a company after the funding. However, the current regulatory framework isn't flexible to that effect.

The debt or equity of a capital stressed company can be bought through two private pooling vehicles primarily. They are:

i) An asset reconstruction company (ARC) and

ii) An alternative investment fund (AIF).

ARC is a capital pooling vehicle regulated by the RBI for the acquisition of non-performing loans by the identified qualified institutional buyers (QIBs). AIF is regulated by the SEBI and can acquire only securities of equity or debt but not loans.

As the ARC is regulated by the RBI it can only acquire debt or it can only acquire the equity limited to the agreed debt to equity conversion. This is also in accordance with the 
agreement during the underlying loan acquisition by the ARC. This implies that the current regulatory framework isn't flexible enough to route the whole investment through a single pooled vehicle by a distressed fund to the investee company. As the SEBI regulates the securities market and the RBI regulates the banking system and its consequent stressed assets, these regulators don't incur the others defined responsibilities. However, for AIFs, it requires an enabling clause and for the ARCs an amendment is required to the SARFAESI Act, as the Act governs the ARCs to bring them under a single pooling vehicle. If the modifications or reforms discussed are implemented the institutional investors would get the flexibility on the capital structure of the investee company once the vehicle is chosen. However, investors need to remember that ARCs are only used for acquiring NPAs (or SMA2 defaults) and the SARFAESI Act cannot enforce the obligations for AIFs.

In the current scenario, even though, the IBC proceedings have been halted for a brief period, this may not help the large real estate projects in reality on the practical grounds other than postponing the immediate death crisis. What is required is to rejuvenate the dead projects with the infusion of funds. The funds would easily flow only when there is a flexible capital outlay structure as discussed above for the investors.
The large volumes of stakeholders present in the realty projects also require rapid changes to uplift it with suitable sops and required reforms. As a more agreed upon and flexible approach is required in the residential real estate projects to protect it from further getting into the status of limbo, a flexible regulatory framework in terms of the capital outlay needed to be sought by the regulators.

\section{REFERENCES}

[1] https://www.cnbctv18.com/real-estate/magicbricks-reports-upto-5-dip-in-realty-prices-in-april-june-property-searches-down27-6280071.htm

[2] https://www.thebalance.com/distressed-debt-investing-and-howit-works-4176037

[3] https://www.newindianexpress.com/opinions/2020/jun/30/flexibi lity-required-for-distressed-funds-in-real-estate-2163216.html

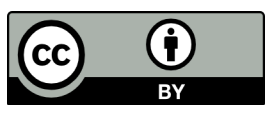

(C) 2020 by the Syed Hasan Jafar. Submitted for possible open access publication under the terms and conditions of the Creative Commons Attribution (CC $\quad$ BY) license (http://creativecommons.org/licenses/by/4.0/). 